\title{
Morals Legislation AND the Establishment Clause
}

\author{
Arnold H. Loewy*
}

In rejecting the argument that morality is an insufficient basis for a law, the Supreme Court, in Bowers v. Hardwick, held: "The law, however, is constantly based on notions of morality, and if all laws representing essentially moral choices are to be invalidated under the Due Process Clause, the courts will be very busy indeed." In rejecting Bowers, a very different Court, in Lawrence v. Texas, ${ }^{3}$ countered: "[T]he fact that the governing majority in a State has traditionally viewed a particular practice as immoral is not a sufficient reason for upholding a law prohibiting the practice . . .."4 The principal thesis of this Essay is that on this point: Lawrence was right and Bowers was wrong. The source of my conclusion is the Establishment Clause, ${ }^{5}$ a clause not mentioned by the opinions in either case. ${ }^{6}$

Others have written about the interrelationship between morals legislation and religion, ${ }^{7}$ but none have attempted to set a standard for the Court to employ whenever it is faced with such a case. In the course of this Essay, I shall develop such a standard.

\section{THE NEED FOR A STANDARD}

If morality simpliciter were enough to justify legislation as Bowers wrongly asserted, ${ }^{8}$ this Essay would not be necessary. However, as Lawrence rightly holds, such is not the case. ${ }^{9}$ Nevertheless, that is hardly a

\footnotetext{
* Graham Kenan Professor of Law, University of North Carolina School of Law. I would like to thank my colleagues William Marshall and Michael Corrado for their helpful comments on this Essay. I also thank my dedicated research assistant, William Cross.

l. 478 U.S. 186 (1986).

2. Id. at 196. Notwithstanding Lawrence v. Texas, 123 S. Ct. 2472, 2486 (2003), which did reject morality as a constitutionally sound basis for laws, the essence of the quoted sentence has not been challenged.

3. 123 S. Ct. 2472 (2003).

4. Id. at 2483 (quoting Bowers, 478 U.S. at 216 (Stevens, J., dissenting)).

5. U.S. CONST. amend. I ("Congress shall make no law respecting an establishment of religion ... .").

6. I do not mean this as a criticism. The point was not argued by any of the parties (or even amici) in either case.

7. See, e.g., Stephen L. Carter, Evolutionism, Creationism, and Treating Religion as a Hobby, 1987 Duke L.J. 977; Kent Greenawalt, Legal Enforcement of Morality, 85 J. CRIM. L. \& CRIMINOLOGY 710 (1995); Michael J. Perry, Why Political Reliance on Religiously-Grounded Morality is Not lllegitimate in a Liberal Democracy, 36 WAKE FOREST L. REV. 217 (2001).

8. Bowers, 478 U.S. at 196.

9. Lawrence, 123 S. Ct. at 2483-84.
} 
unanimous view on the Court. In his Lawrence dissent, among other places, ${ }^{10}$ Justice Scalia maintains that morality, without more, can justify legislation. " Let us test this hypothesis with some hypotheticals.

(1) Alan truly believes that it is immoral for anybody to fail to attend Sunday services at the town's Methodist church. Assume that he persuades the town council, most of whom are also Methodists, to enact an ordinance requiring such attendance. ${ }^{12}$ Barbara intentionally refrains from attending church and is convicted of violating the ordinance. The town defends the ordinance on the ground that its legislators believe that it is immoral to refrain from attending the Methodist church's weekly service absent some sort of medical or personal emergency, which Barbara does not have.

Presumably, Justice Scalia would invalidate the hypothesized ordinance on the ground that it violates the Establishment Clause and possibly the Free Exercise Clause ${ }^{13}$ He would say that morality is a rational basis for a statute, but rationality is insufficient to justify a violation of the First Amendment. ${ }^{14}$ So let us try a slightly less obvious hypothetical.

(2) Cantu is a devout Moslem who believes that eating pork is morally wrong and should be forbidden in his community. He persuades the town council, most of whom are also Moslem, to enact an ordinance forbidding the sale, purchase, or consumption of pork in his community. ${ }^{15}$ Doris serves bacon and eggs to Ed for breakfast at her restaurant. Frances buys three pounds of pork chops from George's butcher shop and consumes them at home the next day. Neither Doris, Ed, Frances, nor George believe that eating pork is immoral. All are convicted under the statute. Once more the town defends the statute on the ground that eating, serving, and selling pork is immoral.

This one might not be so easy for Justice Scalia. Nobody is being required or forbidden to worship in any particular way. Of course, he could say that the rationale for the legislation is religious, but that would prove too much. The rationale for much moral legislation is religious, including laws against consenting adult homosexual sodomy. ${ }^{16}$ And that is precisely the

10. See, e.g., City of Erie v. Pap's A.M., 529 U.S. 277, 310 (2000) ("The traditional power of government to foster good morals (bonos mores), and the acceptability of the traditional judgment (if Erie wishes to endorse it) that nude public dancing itself is immoral, have not been repealed by the First Amendment."); Barnes v. Glen Theatre, 501 U.S. 560, 575 (1991) (see discussion infra Part III).

11. Lawrence, $123 \mathrm{~S}$. Ct. at 2490-91.

12. Of course, I am assuming that under state law, the municipality has the power to enact such ordinances so long as they do not violate some constitutional principle.

13. U.S. CONST. amend. I ("Congress shall make no law respecting an establishment of religion, or prohibiting the free exercise thereof[.]").

14. Compare his concurring opinion in Barnes, 501 U.S. at 572-81 (Scalia, J., concurring), where he indicated that morality is sufficiently rational to sustain a statute but not sufficiently compelling to justify interfering with the First Amendment.

15. Of course, there is the possibility that either the Commerce Clause or federal preemption could invalidate this law, but for purposes of this hypothetical, assume that is not the case.

16. See Bowers v. Hardwick, 478 U.S. 186, 196 (1986) (Burger, C.J., concurring) ("Condemnation of those practices is firmly rooted in Judeao-Christian moral and ethical standards."). 
point. If morality simpliciter can qualify as a rational basis, a community can punish religious dissidents for straying from the straight and narrow.

In assessing an appropriate test, one should first consider the core purpose of the religion clauses. Without attempting to be overly nuanced, it seems basic that, to the greatest extent possible, persons should be free from compulsion to exercise another's religious beliefs in lieu of or in addition to their own. ${ }^{17}$ For that reason, I assume that most readers would agree that the anti-pork legislation is unconstitutional. But given that so much of our legislation is based on Judeo-Christian morality, how can we distinguish legitimate from illegitimate moral legislation?

I propose a test that looks to the purpose of legislating against the particular activity. If the activity involves morality simpliciter, i.e., the legislature simply condemns the activity because it is immoral, the law should be held to violate the Establishment Clause. On the other hand, if the legislation is predicated on purposive morality, i.e., morality that serves a secular function, the law should be sustained.

Some may argue that non-believers could support morals legislation. For example, Helen, an agnostic, may believe that homosexual sodomy should be punished because it is morally wrong. She does not believe in God and concedes that more often than not, participants in homosexual sodomy are benefited by the act. Nevertheless, she thinks that it is morally wrong and should be forbidden. Although I suspect that the number of agnostics sharing Helen's view is small, ${ }^{18}$ I concede that they may exist. However, I contend that the non-purposive morality that Helen supports occupies a place in her life parallel to that of God in the mind of the more traditional believer. ${ }^{19}$ This is so because of her concurrent beliefs in both the moral imperative and social disutility of the statute.

To test whether legislation meets my proposed test, I would ask whether a substantial number of religious skeptics would support the legislation. In the pork hypothetical, it is possible that a few non-Moslems (or nonOrthodox Jews) would support the legislation. For example, Ian, an animal rights activist who would like to ban the slaughter of all animals, might be willing to start with pigs until he can persuade others to forbid the sale of beef and lamb as well. Assuming that Ian represents a tiny minority of the community, I would not uphold the statute. If we did, we effectively would

17. I am not now talking about the right to exemption from otherwise valid laws. See Employment Div,, DHR v. Smith, 494 U.S. 872, 890 (1990). Although elsewhere, I have expressed reservations about that case, see Arnold H. Loewy, Rethinking Free Exercise After Smith and Boerne: Charting a Middle Course, 68 Miss. L.J. 105 (1998), I assume arguendo that the case was correctly decided. What I am speaking of in the text is the right to be free from the imposition of another's religious beliefs. In Smith, nobody believed that peyote was forbidden because some religious beliefs suggested it was immoral. Rather, it and other drugs were forbidden because of the harm the government believed that these drugs inflicted on its users. See Smith, 494 U.S. at 905.

18. Indeed, I know of no significant agnostic or atheistic groups that oppose homosexuality on the grounds of morality. Compare infra note 148, noting the agnostic and atheistic objection to free abortion.

19. According to the Supreme Court, that qualifies as a religious belief. See Welsh v. United States, 398 U.S. 333, 339 (1970); United States v. Seeger, 380 U.S. 163, 176 (1964). 
have permitted a religious majority to make criminals out of their dissident fellow citizens simply because a tiny minority of dissidents approved. Thus, I would require support by skeptics in substantial numbers to ensure that a majority's religious beliefs are not dictating the minority's lifestyle.

In the next section, I will apply my proposed test to the Ten Commandments.

\section{THE TEN COMMANDMENTS ${ }^{20}$}

The Ten Commandments can be divided into three categories: those that government clearly can enforce, those that government clearly cannot enforce, and those that are partially enforceable. Obviously, the first two categories are less controversial than the third, so I shall dispose of them first.

The three Commandments forbidding murder, ${ }^{21}$ theft, ${ }^{22}$ and false testimony against one's neighbor ${ }^{23}$ are clearly permissible. Each of them protects a governmental interest quite independent of abstract morality. The importance to all, believer and nonbeliever alike, of not being victimized by any of these activities is too obvious to require extended defense. So, in the absence of any serious argument to the contrary, I simply assert that these Commandments are governmentally enforceable.

20. For purposes of this Essay, I rely primarily on the New International Version and Jewish version of the Ten Commandments. The Catholic version uses a slightly different numbering and contains minor substantive differences. I do not believe that any of these differences matter in regard to the substantive points being made. The Ten Commandments are as follows:

"I am the LORD your God, who brought you out of Egypt, out of the land of slavery.

"You shall have no other gods before me.

"You shall not make for yourself an idol in the form of anything in heaven above or on the earth beneath or in the waters below. You shall not bow down to them or worship them; for I, the LORD your God, am a jealous God, punishing the children for the sin of the fathers to the third and fourth generation of those who hate me, but showing love to a thousand generations of those who love me and keep my commandments.

"You shall not misuse the name of the LORD your God, for the LORD will not hold anyone guiltless who misuses his name.

"Remember the Sabbath day by keeping it holy. Six days you shall labor and do all your work, but the seventh day is a Sabbath to the LORD your God. On it you shall not do any work, neither you, nor your son or daughter, nor your manservant or maidservant, nor your animals, nor the alien within your gates. For in six days the LORD made the heavens and the earth, the sea, and all that is in them, but he rested on the seventh day. Therefore the LORD blessed the Sabbath day and made it holy.

"Honor your father and your mother, so that you may live long in the land the LoRD your God is giving you.

"You shall not murder.

"You shall not commit adultery.

"You shall not steal.

"You shall not give false testimony against your neighbor.

"You shall not covet your neighbor's house. You shall not covet your neighbor's wife, or his manservant or maidservant, his ox or donkey, or anything that belongs to your neighbor."

Exodus 20:2-17 (New International Version). One construction of the commandment that forbids stealing suggests that it is kidnapping, rather than theft, that is forbidden. See Steve Zeisler, Protection of Property and Reputation (Oct. 21, 1988), available at http://www.pbc.org/dp/Zeisler/4187.html.

21. Exodus 20:13.

22. Id. 20:15. This may also refer to kidnapping. See Zeisler, supra note 20.

23. Exodus $20: 16$. This is essentially perjury. 
Quite clearly, the state cannot enforce prohibitions against non-belief in God, ${ }^{24}$ making graven images of God, ${ }^{25}$ or taking the Lord's name in vain. ${ }^{26}$ To the extent that these provisions also forbid blasphemy, it is quite clear that both the Establishment Clause and the Freedom of Speech Clause preclude punishment for such behavior. ${ }^{27}$ The Commandment against coveting is also unenforceable. ${ }^{28}$ One need not go so far as the Wall Street "greed is good"29 aphorism to recognize that a government has no power to limit a person's aspirations. Even Jimmy Carter confessed to lusting in his heart. ${ }^{30}$ Our traditions of not punishing a person for her thoughts, i.e., the requirement of actus reus, ${ }^{31}$ coupled with the difficulties of proof would render such a charge fanciful at best. To illustrate the absurdity of such a prosecution, suppose a policeman attending a party overheard Jane say: "I just love my neighbor Kevin's Mercedes. I wish I owned it." Could we even imagine the policeman saying: "Okay Jane, you're under arrest for coveting."?

Having discussed the clearly constitutional and clearly unconstitutional enforcement of the Ten Commandments, let me focus on the three that probably should be deemed partially enforceable: the Commandments concerning Sabbath, parental respect, and adultery.

The Supreme Court has had an opportunity to consider a secular version of Sabbath in McGowan v. Maryland..$^{32}$ Its analysis was quite consistent with that proposed herein. In upholding laws of religious origin, the Court focused on the current secular support for the law..$^{33}$ Noting that labor unions support Sunday closing laws, ${ }^{34}$ and that the value of having the same day each week as a quiet recreational day benefited all families, regardless

\footnotetext{
24. Id. $20: 2$.

25. Id. 20:4-6.

26. Id. 20:7.

27. While the Supreme Court has never explicitly ruled that prosecution for blasphemy is unconstitutional, cases such as Joseph Burstyn, Inc. v. Wilson, 343 U.S. 495, 506 (1952) (holding that a ban on films that are 'sacrilegious' is unconstitutional) and Cantwell v. Connecticut, 310 U.S. 296, 311 (1940) (holding that the charges of breaching the peace against a man for playing a record that attacked the religion of two others could not stand) strongly suggest that banning expression merely because it offends a person's religious sensibilities cannot withstand First Amendment scrutiny in terms of both the Free Speech and Establishment Clauses. See generally Susan W. Brenner, Complicit Publication: When Should the Dissemination of Ideas and Data be Criminalized?, 13 ALB. L.J. SCI. \& TECH. 273, 304-07 (2003).

28. Exodus 20:17. The Catholic version of the Ten Commandments forbids coveting in both the Ninth and Tenth Commandments.

29. WALL STREeT (20th Century Fox 1987) (Michael Douglas line from the movie).

30. In an interview in Playboy Magazine, Carter famously admitted, "I've looked on a lot of women with lust. I've committed adultery in my heart many times." Roben Sheer, Playboy Interview: Jimmy Carter, A Candid Conversation with the Democratic Candidate for the Presidency, Playboy MaG., Nov. 1976, at 86.

31. WAYNE LAFAVE, CRIMINAL LAW 10 (4th ed. 2003) ("[C]onduct, to be criminal, must consist of something more than a mere bad state of mind.").

32. McGowan v. Maryland, 366 U.S. 420 (1961). See also Two Guys from Harrison-Allentown, Inc. v. McGinley, 366 U.S. 582 (1961).

33. McGowan, 366 U.S. at 435.

34. Id.
} 
of religious convictions, ${ }^{35}$ the Court upheld the Sunday closing laws as consistent with Establishment Clause principles. ${ }^{36}$

Now let us vary the situation. Assume that a community with the autonomy to make its own Sabbath laws is composed of sixty percent Orthodox Jews. Assume that this community chooses to compel business closure for the period from sundown Friday through sundown Saturday. ${ }^{37}$ Presumably this statute would be sustained for the same reasons as the Maryland statute in McGowan. But suppose the community added a provision forbidding driving in the community during that timeframe. ${ }^{38}$

Now, let us suppose that Laura, a non-Orthodox Jew, drove on a Friday night from her home in the community to another home three miles away to attend a party. While en route, she received a ticket for driving on Friday night. Should the courts uphold her ticket? The answer may depend on which of three rationales are offered for the "no driving ordinance."

The easiest ground for invalidating the ordinance would be if it was predicated upon the religious duty not to work, including drive, on the Sabbath. Obviously, no reasonable skeptic could support legislation enacted on such a ground, and it should therefore be unconstitutional. Suppose, however, that the ordinance was based on the desire to add to the quiet of the day. The entire community would know that from sundown Friday to sundown Saturday, there would be no vehicular traffic. The day would be quiet, unlike any other. Although a somewhat similar rationale upheld the Sunday closing laws, this seems to carry the analogy too far. Undoubtedly a few nonbelievers would like the advantage of a quieter community. But most would not. Many of those that would support a quieter day probably would prefer to eliminate automobile traffic generally. The end result would be a great inconvenience to the automobile driving public in the service of a majority religion-probably an unconstitutional result. ${ }^{39}$

The strongest ground for upholding the ordinance might be safety. The presence of a vastly larger-than-normal number of pedestrians (including children $)^{40}$ on the surface seems like a good non-religious reason for limiting vehicular traffic. If, during the year preceding passage of this ordinance, a significant number of vehicular/pedestrian accidents or near-accidents had occurred during the twenty-four hour Sabbath period, a powerful case could

\footnotetext{
35. Id. at 450 .

36. Id. at 453.

37. The time of the Jewish Sabbath.

38. Presumably there would need to be two exceptions necessary even to debate the constitutionality of this ordinance. First, there would have to be an emergency exception. I cannot imagine convicting a person for driving on Saturday to get a dying relative to the hospital. Second, streets that carried a substantial amount of interstate commerce would probably need to be excepted. The Supreme Court does not take kindly to state or local laws that significantly interfere with the movement of interstate commerce. $C f$. Kassel v. Consol. Freightways Corp., 450 U.S. 662, 679 (1981) (overturning an lowa law barring the use of 65-foot double-length tractor-trailers on most lowa highways).

39. Not unlike the animal rights activist's opposition to eating pork being insufficient to sustain the anti-pork ordinance. See discussion supra Part I.(2).

40. The additional pedestrian traffic is caused by the religious limitation on driving adhered to by sixty percent of the community.
} 
be made for forbidding vehicular traffic at that time. If, on the other hand, accidents were not significantly higher at that time, in part because fewer residents chose to drive in violation of the Lord's Commandment, the safety rationale would not seem very powerful.

On balance, it seems unlikely, but not impossible, that a legitimate rationale for sustaining Laura's traffic ticket can be found. The important thing is that, as in McGowan, any limitation on what the populace can do on the Sabbath must be justified by secular concerns, lest a religious majority coopt its dissidents into being reluctant participants in a religious ritual. ${ }^{41}$

The Commandment that compels parental honor is obviously not completely enforceable. If Mike hates his father, Norman, and wants to publicize that hatred to both his father and the world, it is hard to see what governmental interest could stop him. ${ }^{42}$ On the other hand, suppose that Mike's home state enacts legislation compelling adult children to care for their aging parents under some circumstances. ${ }^{43}$ Suppose further that Norman is sufficiently needy that Mike's duty to support falls within the statutory prescription. Could Mike simply say: "I'm sorry, but I hate my father and I refuse to honor him no matter what the Fifth Commandment says."?

Mike should lose. Of course, he cannot be compelled to honor his father in the biblical sense of the term, but he can be compelled to support his father. While religious groups may be pleased to have a law compelling tangible support toward those that the Commandment compels honor, that is not where all, or even most, of the support for such legislation emanates. Reasonable skeptics in substantial numbers would likely support such legislation because it is designed to reduce welfare roles by forcing individuals, rather than the state, to care for relatives. ${ }^{44}$ So, while Mike can't be forced to honor Norman in his heart, he can be forced to honor him by providing sufficient support to keep him off the welfare roles.

Finally, the Commandment against adultery is partially, but not completely, enforceable by the state. Assume that Olivia, while married to Paul, engages in sexual intercourse with Quincy. Surely, the state can, if it chooses, create a divorce law that would allow Paul a larger share of the marital property in a divorce proceeding than that to which he would be entitled if Olivia had not committed adultery. ${ }^{45}$ This is because Olivia has

41. McGowan, 366 U.S. at 435.

42. At least assuming his expressions do not amount to either libel or harassment, standards that do not vary according to family lineage.

43. Many states have such requirements. E.g., CAL. FAM. CODE $§ 4400$ (West 2000); IOWA CODE ANN. § 252.2 (West 1999). For further discussion of this issue, see Joann Blair, "Honor Thy Father and Mother"-But for How Long?-Adult Children's Duty to Care for and Protect Elderly Parents, 35 U. LOUISVILlE J. FAM. L. 765 (1996); and Shannon Frank Edelstone, Filial Responsibility: Can the Legal Duty to Support our Parents be Effectively Enforced?, 36 FAM. L.Q. 501 (2002).

44. The Federal Trade Commission estimates that 22.4 million households are providing care for family or friends aged fifty or older. Federal Trade Commission, Aging Parents and Adult Children Together (Oct. 1998), at http://www.ftc.gov/bcp/conline/pubs/services/apact/ (last visited July 15, 2003). See also Katie Wise, Caring for Our Parents in An Aging World: Sharing Public and Private Responsibility for the Elderly, 5 N.Y.U. J. LEGIS. \& PUB. POL'Y 563 (2002).

45. See, e.g., MD. CODE ANN. FAM. LAW § 8-205 (1999). See also Ohm v. Ohm, 431 A.2d 1371, 
breached a very special contract with Paul (marriage) in a manner that warrants a financial penalty.

Once more, one need not be a religious insider to accept this conclusion. Monogamous marriages are sufficiently fundamental to our society that, at least where the parties agree to them, the law can punish their breach. Criminalizing adultery, as some states still do, ${ }^{46}$ should be constitutionally sustainable. Although a breach of contract does not ordinarily give rise to criminal liability, marriage is no ordinary contract. ${ }^{47}$ Adultery can devastate people of all religious beliefs, as well as people bereft of religion. Whether the state does more harm than good in punishing adultery is a separate question. But even assuming that employing the criminal law is unwise, it does not follow that it is unconstitutional.

The Commandment, however, is broader than the state's interest. Under the Commandment, even adultery committed with the permission or active connivance of the supposedly injured spouse would be subject to punishment. So in my hypothetical, if Paul had actively encouraged Olivia to be intimate with Quincy, Olivia would be guilty anyway. Indeed, Paul could well be guilty of aiding and abetting. ${ }^{48}$ It is difficult to see any non-religious justification for such liability. Consequently, the Establishment Clause should preclude liability (criminal or civil) in those circumstances.

In sum, three of the Commandments are fully enforceable by government, ${ }^{49}$ four are unenforceable, ${ }^{50}$ and three are partially enforceable. ${ }^{51}$ But most importantly, enforcement must be predicated on something other than morality simpliciter.

\section{JUSTICE SCALIA'S HYPOTHETICALS}

In his Lawrence dissent, Justice Scalia contended that:

We ourselves relied extensively on Bowers when we concluded, in Barnes $v$. Glen Theatre, Inc., that Indiana's public indecency statute furthered "a substantial government interest in protecting order and morality." State laws against bigamy, same-sex marriage, adult in-

1381 (Md. Ct. Spec. App. 1981) (" [U]nder the statute . . adultery is a factor . . in making an award of alimony ... [and] making a monetary award.").

46. See, e.g.. ALA. CODE $\S 13 A-13-2$ (1975); D.C. CODE ANN. $§ 22-201$ (2001); 720 ILL. CoMP. STAT. ANN. 5/11-7 (West 2002).

47. See Maynard v. Hill, 125 U.S. 190, 210-11 (1888).

48. Cf. Griswold v. Connecticut, 381 U.S. 479, 484 (1965) (reversing the conviction of the operator of a Planned Parenthood Center for aiding and abetting the use of contraceptive devices). The reversal in Griswold was predicated entirely on the unconstitutionality of convicting the principals. See discussion infra Part V.A.

49. You shall not murder. Exodus 20:13. You shall not steal (or kidnap). Id. 20:15. You shall not bear false witness against your neighbor. $I d$. 20:16.

50. I am the Lord, your God. Id. 20:2. You shall have no other Gods before me. Id. 20:3. You shall not take the name of the Lord in vain. Id. 20:7. You shall not covet. Id. 20:17.

51. Remember the Sabbath Day by keeping it holy. Id. $20: 8$. Honor your father and mother. Id. 20:12. You shall not commit adultery. Id. 20:14. 
cest, prostitution, masturbation, adultery, fornication, bestiality, and obscenity are likewise sustainable only in light of Bowers' validation of laws based on moral choices. ${ }^{52}$

Justice Scalia, of course, did not distinguish between purposive and nonpurposive morality. If he had, he would have been able to uphold some of the statutes that he referenced. Others, however, would be correctly condemned as unconstitutional.

Starting with Barnes, Justice Scalia is correct that a plurality of the Court $^{53}$ seemed to hold that morality simpliciter not only justified a law but also constituted an important or substantial governmental interest. ${ }^{54}$ The plurality thereby justified the application of a prohibition-against-publicnudity statute to barroom nude dancing despite freedom of speech concerns. ${ }^{55}$ Indeed, the Barnes plurality, along with Justice Scalia's conclusion that morality constituted a rational basis, which was all the state needed, ${ }^{56}$ is one of Bowers's most pernicious progeny. The problem with such reasoning is that the state need not explain why it is regulating; it merely needs to wrap itself in morality.

In a follow-up to Barnes, City of Erie v. Pap's A.M., ${ }^{57}$ basically the same plurality eschewed morality as a basis for its decision, preferring to rely on the pernicious secondary effects that nude dancing had on the community. ${ }^{58}$ While one need not endorse all of the Erie plurality's logic, ${ }^{59}$ it at least had the virtue of seeking a legitimate secular justification independent of abstract morality. ${ }^{60}$ Although I do not believe that the Erie plurality justified its result under the Freedom of Speech Clause of the First Amendment, I do believe that it satisfied Establishment Clause concerns. One need not hold to any particular religious belief to be concerned about activity that may increase crime in its immediate locale.

As for the specific issue in the Barnes case, Justice Scalia starkly argued that protecting morality rather than protecting the non-consenting public from offense was the basis for the law. ${ }^{61}$ Specifically, he said:

\footnotetext{
52. Lawrence v. Texas, 123 S. Ct. 2472, 2490 (2003) (Scalia, J., dissenting) (citations omitted).

53. Surprisingly including Justice Kennedy, the author of Lawrence.

54. See Barnes v. Glen Theatre, 501 U.S. 560 (1991).

55. Id. at 569 . Interestingly, Justice Scalia appeared to chide his colleagues for treating morality as an important or substantial interest rather than merely a rational basis. See id. at 580.

56. Justice Scalia did not believe that speech was implicated because in his view, nudity, even in dance, was not protected by the First Amendment. Id. at 572-79.

57. 529 U.S. $277(2000)$.

58. Id. at 289-302. The Barnes plurality consisted of Rehnquist, O'Connor, and Kennedy. Barnes, 501 U.S. at 562. The Erie plurality consisted of those three plus Breyer, who was not on the Court when Bames was decided. Erie, 529 U.S. at 282.

59. Indeed, I do not endorse it, largely for the reasons suggested in Justice Stevens's persuasive dissent. Id. at 317 (Stevens, J., dissenting). See Arnold H. Loewy, The Use, Nonuse, and Misuse of Low Value Speech, 58 WASH. \& LEE L. REV. 195, 219-20 (2001).

60. Id. at 289-302.

61. Barnes, 501 U.S. at 574-75.
} 
Perhaps the dissenters believe that "offense to others" ought to be the only reason for restricting nudity in public places generally, but there is no basis for thinking that . . . Thoreauvian "you-may-dowhat-you-like-so-long-as-it-does-not-injure-someone-else" beau ideal-much less for thinking that it was written into the Constitution. The purpose of Indiana's nudity law would be violated, I think, if 60,000 fully consenting adults crowded into the Hoosier Dome to display their genitals to one another, even if there were not an offended innocent in the crowd. ${ }^{62}$

I am certainly not contending that what he calls the "Thoreauvian . . . beau ideal" is written into the Constitution. ${ }^{63} \mathrm{I}$ assume that people are not free to engage in actual or potentially self-destructive behavior such as driving without a seatbelt or motorcycle helmet or consuming potentially harmful drugs. But, where the rationale for the law is morality simpliciter, the Establishment Clause is implicated in a way that it is not with other victimless laws.

In regard to Justice Scalia's hypothetical, there is no doubt that a city could refuse to rent its stadium for the activity that he described. ${ }^{64}$ Assuming, however, that the function was held at a comparably-sized private stadium but because of advertising, the public was aware of it, the secondary effects argument might be persuasive. The point is that some purposivemoralistic position, like secondary effects, would have to be argued. If, however, Rhonda, the owner of a large mansion, decides to invite 200 of her closest friends to a party for the purpose of mutual genital exposure, and each of the guests is encouraged to invite additional friends, it is difficult to see how the state could punish that activity in the absence of evidence that some harm was being done.

Let us consider Scalia's other hypotheticals in the order that he presented them, starting with bigamy. ${ }^{65}$ In the run-of-the-mine bigamy case, morality simpliciter is neither the only nor even the primary justification. Assume that Sam, already married to Thelma, marries Ursula. Neither Thelma nor Ursula knows of each other's existence, largely because of Sam's efforts to keep it that way. It matters little whether the parties are devout Christians or first order heretics; both women have been deceived. Sam has committed a severe offense against both of his innocent wives. Prosecuting him is clearly based on purposive morality and should be constitutional.

\footnotetext{
62. Id. (emphasis in original).
}

63. Id.

64. Nudity per se is not speech, as conceded by even the Erie and Barnes dissenters. See Erie, 529 U.S. at 326; Barnes, 501 U.S. at $587 \mathrm{n} .1$ (White, J., dissenting)). I see no problem with a community simply choosing not to make its facilities available for that sort of activity.

65. Lawrence v. Texas, 123 S. Ct. 2472, 2490 (2003) (Scalia, J., dissenting). 
Now let us vary the hypothetical. Suppose that Sam and Thelma mutually agree that Sam should take another wife and that the three of them should live together. They approach Ursula, a friend of both with the suggestion that she be the second wife. After some discussion about the logistics of the arrangement, all parties believe that it is in their mutual and individual interests to contract this additional marriage. Should it be constitutionally possible to prosecute Sam for bigamy under those circumstances?

Obviously, this hypothetical is closer to morality simpliciter than the first. Nevertheless, the state should be able to prosecute Sam. By defining marriage as a relationship between one man and one woman, the state limits the benefits it can potentially distribute. Tax benefits, welfare benefits, and social security benefits, among others, are predicated on marriage. Obviously, if one man is free to have two (or for that matter, ten) wives, or a woman is free to have multiple husbands, the whole structure of governmental benefits could be affected. Consequently, a law forbidding multiple simultaneous civil marriages for one person is reasonably related to protecting the public fisc and thus cannot be condemned as a violation of the Establishment Clause.

On the other hand, without the benefit of a civilly-sanctioned marriage, it seems clear that Sam, Thelma, and Ursula can live the life they contemplate. That is, if the three of them choose to set up a household together, there is no argument, apart from morality simpliciter, that precludes their so acting. Prior Supreme Court precedent protects their right to procreate, married or single. ${ }^{66}$ And Lawrence, unless extremely artificially constricted, assures their right to sexual privacy. ${ }^{67}$

Given that this lifestyle is constitutionally protected, should those living it be subject to prosecution for consecrating it with a religious marriage? For example, in our hypothetical, if Sam and Ursula are married, with Thelma's approval, by a minister in a religious ceremony, ${ }^{68}$ which does not purport to also be a civil marriage, should any of them be subject to criminal prosecution? Such a prosecution would certainly seem to be predicated on abstract morality and as such should be unconstitutional. Indeed, as I have argued elsewhere, the Free Exercise Clause, as well as the Establishment Clause, should protect their religious marriage. ${ }^{69}$

Scalia's next hypothetical, same-sex marriage, is obviously intended to give the Court pause in adopting what he sees as an ill-considered move

66. See Eisenstadt v. Baird, 405 U.S. 438, 452-55 (1972).

67. Cf. supra text between notes 48-49.

68. Although the Mormon Church has officially outlawed polygamy, many sources suggest that tens of thousands of Christian polygamists still practice "plural marriage." One anti-polygamy group, Tapestry Against Polygamy, suggests that there are more than 100,000 polygamists in the western United States alone. Tapestry Against Polygamy, Frequently Asked Questions, at http://www.polygamy.org/faq.shtml (last visited Aug. 15, 2003). For a more in-depth discussion of antipolygamy laws and the Establishment Clause, see Stephanie Forbes, "Why Just Have One?": An Evaluation of the Anti-Polygamy Laws Under the Establishment Clause, 39 Hous. L. REv. 1517 (2003). 69. See Arnold H. Loewy, Rethinking Free Exercise of Religion after Smith and Boerne: Charting a Middle Course, 68 Miss. L.J. 105 (1998). 
away from morality-based legislation. ${ }^{70}$ There is, however, a huge difference. The inability to marry does not punish the homosexual for acting outside the dictates of somebody else's religion. As with the analysis of bigamy, marriage is a scarce commodity. To be sure, the situation is not identical to bigamy. If Victor, a homosexual, wishes to marry Wilbur, the potential impact on governmental resources would be no greater than if he chose to marry Wilma. Nevertheless, I do not believe that a state's dispensing a benefit only to a preferred relationship should be treated the same as its prohibition of the disfavored relationship. ${ }^{71}$ Thus, if a state wishes to reserve the scarce resources of its marital benefit policy to heterosexual couples, I do not believe that Establishment Clause principles should preclude it from doing so. ${ }^{72}$

This is not to suggest that allowing such marriages may not be the wiser course of action. One of the arguments sometimes made against homosexual unions is the spread of disease, especially AIDS. Although Texas could not have relied on this argument in Lawrence because its statute forbade oral and anal sex, ${ }^{73}$ and the former is actually a less efficient conductor of AIDS than penile/vaginal sex..$^{74}$ Monogamous homosexual, as well as heterosexual, sex is almost certainly safer than sex with multiple partners. Consequently, prudence may well dictate sanctioning homosexual marriages, but the Establishment Clause does not.

Continuing with Justice Scalia's laundry list, adult incest has always been punished primarily because of science, not theology. ${ }^{75}$ While biblical injunctions against incest do exist, ${ }^{76}$ incest is forbidden because science has determined that incest creates an unacceptably high risk of transmitting and even mutating unhealthy genetic characteristics. As with Sunday closing laws, ${ }^{77}$ deific disapproval of incest is not the primary force behind such legislation. ${ }^{78}$ So long as scientific data suggests that incest carries an unaccept-

\footnotetext{
70. Lawrence, 123 S. Ct. at 2490 (Scalia, J., dissenting).

71. Compare Roe v. Wade, 410 U.S. 113 (1973) (upholding the constitutional right to abortion), with Harris v. McRae, 448 U.S. 297 (1980) (denying the right to medical compensation for an abortion even where the same or greater compensation would have been available for childbirth), and Rust $v$. Sullivan, 500 U.S. 173 (1991) (upholding a law that prohibited doctors who received Title X federal money from discussing abortion with their patients).

72. Typically, states do not allow individuals who share a household and care for each other to obtain all of the benefits of spouses even when there is no moral impropriety in their relationship, e.g., two sisters who share a household for many years in a totally asexual relationship. See John V. Orth, Night Thoughts: Reflections on the Debate Concerning Same-Sex Marriage, 3 NEV. L.J. 560 (2003). Of course, for the reasons already presented, I do not believe that the state can punish a religious marriage between two (or more) homosexuals.

73. Lawrence, 123 S. Ct. at 2476.

74. Centers for Disease Control, Can I Get HIV from Performing Oral Sex?, at http://www.cdc.gov/hiv/pubs/faq/faq19.htm (last visited Sept. 21, 2003) ("[T] sex] is less than that of unprotected anal or vaginal sex.").

75. Lawrence, 123 S. Ct. at 2490 (Scalia, J., dissenting).

76. Leviticus 18:6 ("No one is to approach any close relative to have sexual relations."). See also id. 18:7-18, which goes into more detail.

77. See supra text accompanying note 40.

78. Instead, such laws are generally based on the dangers of genetic "inbreeding." See, e.g., ALA. CODE $\S 13 \mathrm{~A}-13-3$ (1975) ("There is secular utility in a prohibition against such inbreeding as would
} 
able risk of deformed children, the politicians are not likely to subject the populace to this risk. ${ }^{79}$ Ironically, adult homosexual incest may be protected because the secular justification for precluding heterosexual incest is not present in regard to homosexual incest.

Prostitution is probably subject to regulation on two grounds: (1) its tendency to adversely impact the quality of life in the neighborhood surrounding the meeting place between prostitutes and johns, and (2) its impact on public health. Quality of life issues are not predicated on religiosity or morality. Rather they are predicated on rendering the neighborhood safe for individuals and families to walk, play, and shop. ${ }^{80}$ The disease prevention rationale is little different from laws precluding food and drugs not approved by the FDA. Both are more concerned with the health of the body than of the soul. ${ }^{81}$

On the other hand, it is possible that some anti-prostitution laws are overly broad. While solicitation for purposes of prostitution can have an adverse impact on neighborhood quality of life, discreet sexual liaisons for compensation do not. Furthermore, those who engage in promiscuous sex for fun are probably at least as likely to contract sexually-transmitted diseases as are those who engage in it for profit. So, if Xaviera runs a discreet house of prostitution, which does not adversely impact the quality of life in the community, and creates no more of a health risk than Yetta and Zach face when engaging in sexual intercourse after meeting for the first time at a local bar, perhaps prosecution would be inappropriate.

More important than the answer, however, is the nature of the question. The state would no longer be able to say, "You violated our standards, which were based on abstract morality, therefore we will convict you." Instead, the state must establish a purpose behind the morality to justify a conviction. Whether the state could justify liability in Xaviera's case is a close question, but more importantly, a legitimate question. To resolve an easier case, it should not be permissible to punish a man for transporting a woman across state lines for immoral purposes, i.e., having voluntary sex with him. ${ }^{82}$

result in defective offspring by reason of the higher probability of unfavorable, recessive genes combining in the children of parents within certain blood relationships.").

79. Of course, this assumes that the scientific data that supports such legislation is sufficiently powerful to warrant this limitation on human freedom. Compare Robin Bennet et al., Genetic Counseling and Screening of Consanguineous Couples and Their Offspring: Recommendations of the National Society of Genetic Counselors, J. GenETIC COUNSELING 11, 97-119 (2002) (suggesting that the genetic dangers of cousins marrying is not appreciably greater than that of other couplings), with J. Jancar \& S.J. Johnston, Incest and Mental Handicap, 34 J. MENTAL DEFICIENCY RES. 483 (1990) (identifying the transmission of mental handicaps as a danger of inbreeding). The resolution of this scientific question is beyond the scope of this Essay.

80. This point is discussed in greater detail in conjunction with obscenity. See infra text accompanying notes 93-96.

81. The health of the soul being the prototype interest that the Establishment Clause leaves to the church rather than the state.

82. See Caminetti v. United States, 242 U.S. 470 (1917) (upholding a conviction for violating the Mann Act, 18 U.S.C. $\$ 398$ (current version at 18 U.S.C. $\$ 2421$ (2000)), on just such a basis). Cf. Ge- 
As for masturbation, it is difficult to fathom how it made Scalia's laundry list. ${ }^{83}$ I am not aware of any masturbation prosecution in my lifetime, nor can I imagine why any state would want to indulge in such a prosecution. Indeed, it is an activity that psychologists sometimes recommend to patients in lieu of less socially appropriate sexual expressions. ${ }^{84}$ So, if, preLawrence, it were theoretically prosecutable under the morality simpliciter rubric, it is hard to see what is lost by eliminating that possibility.

Perhaps Scalia was concerned with public or mutual masturbation. As to the former, there is little doubt that prosecution is still permitted. Like public urination, the crime offends against quality of life and possibly public health, and thus the state need not rely on morality simpliciter to justify its punishment. Mutual consensual private masturbation is almost certainly protected after Lawrence, though given the activity protected in Lawrence, it is hard to see why anyone would care.

Fornication is undoubtedly now protected unless Lawrence is read incredibly narrowly. ${ }^{85}$ As a practical matter, Lawrence did not change the law on the subject. ${ }^{86}$ Although no case had previously explicitly constitutionalized the right to fornication, Eisenstadt $v$. Baird held that single people had the same procreation rights as married people. ${ }^{87}$ Presumably that meant a single person could engage in sexual intercourse with another single person for the purpose of procreation. The decision itself allowed single people equal access to contraception to protect their right not to procreate. ${ }^{88}$ Of course, single people could have protected that right just fine by remaining celibate. Obviously, the Court did not consider that a reasonable alternative to protect their right not to procreate. Consequently, it seems hard to understand Eisenstadt as anything other than the birth of a constitutional right to fornication. But to the extent that Eisenstadt did not create such a right, Lawrence necessarily did.

bardi v. United States, 287 U.S. 112 (1932) (rejecting a conspiracy conviction of the same charge only because a man and a woman could not conspire to commit a crime that required both to commit it).

83. Lawrence v. Texas, 123 S. Ct. 2472, 2490 (2003) (Scalia, J., dissenting).

84. This is primarily "because it provides a way to satisfy [unhealthy or dangerous] needs through 'fantasy .. . [and thus] avoid acting out fantasies with innocent victims." 'Vernon R. Padgett et al., Pornography, Erotica, and Attitudes Toward Women: The Effects of Repeated Exposure, 26 J. SEX RES. 479, 480 (1989) (quoting C. Crespault, Sexual Fantasies and Visualization of "Pornographic Scenes," 8 J. SEX. RES. 154-55 (1972)). Masturbation has also been used to recondition sex-offenders and sexual disorders in marital relationships. See W. Charles Lobitz \& Joseph LoPiccolo, The Role of Masturbation in the Treatment of Orgasmic Dysfunctions, 2 ARChIVES SeXUAL BeHaV. 163 (1972); Symposium, Critical Perspectives on Megan's Law: Protection vs. Privacy, 13 N.Y.L. SCH. J. HuM. RTS. 1, 133 (1996) (discussing "masturbation satiation," a reconditioning treatment used with sex offenders) (quoting Marty Klein, Sex, Crime \& Punishment: Are We Willing to Rehabilitate Sexually Dangerous People? Playboy Mag., May 1995, at 44).

85. Adultery has already been analyzed. See supra text accompanying notes $45-48$.

86. See Lawrence, 123 S. Ct. at 2484.

87. Eisenstadt v. Baird, 405 U.S. 438, 453 (1972).

88. Id. 
Justice Scalia's next concern, bestiality, undoubtedly has a religious pedigree dating back to at least the covenant between God and Noah ${ }^{89}$ However, today's animal rights advocates are not necessarily religious. ${ }^{90}$ Without question, forced sex by a human with an animal constitutes human imposition upon the animal and can be condemned as animal cruelty. Preventing animal suffering should certainly qualify as purposive morality and, as such, should be sustained as consistent with the Establishment Clause. ${ }^{91}$

Justice Scalia concludes his list with obscenity. ${ }^{92}$ Perhaps by describing it as morals legislation, he is accepting Louis Henkin's observation of more than forty years ago that: "Obscenity . . . is not crime[; it] is $\sin .{ }^{.93}$ There is, however, some purposive justification for anti-obscenity laws. The Court explained the state's interests this way in Paris Adult Theatre ${ }^{94}$ thirty years ago: "These include the interest of the public in the quality of life and the total community environment, the tone of commerce in the great city centers, and, possibly, the public safety itself. ${ }^{, 95}$ Although, as I have said elsewhere, I do not believe that these reasons should have been held sufficient to justify anti-obscenity legislation as against a Freedom of Speech challenge, ${ }^{96}$ they are sufficient to show purposive, as opposed to abstract, morality.

On the other hand, had Stanley v. Georgia ${ }^{97}$ not upheld the free speech right to private possession of obscenity, the Establishment Clause should have. The only serious argument made against private possession is that some people are offended that other people in their society possess such material. ${ }^{98}$ Obviously, this rationale cannot count. Assume that $\mathrm{Al}$ is terribly offended that Betty possesses obscenity. He is also offended that she does not attend the Second Street Baptist Church. Nobody would argue that protecting $\mathrm{Al}$ from his offense at Betty's church non-attendance could count as a legitimate governmental purpose. Why then should his offense at Betty's

89. See Lawrence, 123 S. Ct. at 2490 (Scalia, J., dissenting). In the Jewish tradition, the Noahide laws are pre-Abrahamic laws given to all humanity based on a covenant between Noah and God. Laws against both sex with animals and cutting off limbs of living animals were forbidden in the original charter between God and Noah after the flood. See Rabbi Dr. Shimon Cowen, Foundations of the Noahide Laws, 3 J. JuDAISM \& CiVILIZATION 38-4I (2000).

90. For a discussion of the secular rationale for protecting animal rights, see Peter D. Wilson, Secular Ethics and Animal Rights, available at

http://www.infidels.org/library/modern/peter_wilson/ethics.html (last visited Aug. 15, 2003).

91. See generally Kent Greenawalt, The Limits of Rationality and the Place of Religious Conviction: Protecting Animals and the Environment, 27 WM. \& MARY L. REV. 1011 (1986).

92. Lawrence, 123 S. Ct. at 2490 (Scalia, J., dissenting).

93. Louis Henkin, Morals and the Constitution: The Sin of Obscenity, 63 COLUM. L. REv. 391,395 (1963).

94. Paris Adult Theatre I v. Slaton, 413 U.S. 49 (1973).

95. Id. at 58.

96. See Arnold H. Loewy, Obscenity, Pornography, and First Amendment Theory, 2 WM. \& MARY BILL RTS. J. 471 (1993).

97. 394 U.S. 557 (1969).

98. See id. at 565-66. Although there was some evidence that reading obscenity was harmful to its readers, it was so insubstantial that the Court rightly refused to take it seriously. See id. at $565 \mathrm{n.8}, 565$ 66. 
reading habits count? Both are predicated on Betty's failure to adopt Al's concept of sin. Neither should qualify as a crime.

Plausibly, some of the post-Stanley decisions have narrowed the right to purchase obscenity beyond that which is justified. For example, in United States $v$. Orito ${ }^{99}$ the Court upheld an indictment for carrying several reels of obscene film in a briefcase on an airplane in interstate commerce. ${ }^{100} \mathrm{Al}$ though Orito may have had enough films to presume that he was planning to market them, such was not required to obtain an indictment. ${ }^{101}$ Rather, the Court simply held that Stanley was relevant only where the obscenity was actually found in the home. ${ }^{102}$

But why shouldn't discreet sales of obscenity be permitted? Assuming that sales take place in such a manner as not to affect the quality of life or tone of commerce in the city centers (or elsewhere), what harm is done by a quiet sale of obscene material? By way of analogy, the Court has held that undue limits on contraceptive sales frustrate the constitutional right to use contraceptives. ${ }^{103}$ It may well be that the implications of Lawrence will cause the Supreme Court to rethink post-Stanley cases, such as Orito. If so, we would be better off for it.

Before leaving Justice Scalia's list of horribles, I would like to consider a few more that he mentioned in his earlier Barnes opinion: "sadomasochism, cockfighting, . . . suicide, [and] drug use . ..." ${ }^{04}$ All of these laws are clearly sustainable. Cockfighting, of course, constitutes cruelty to animals. ${ }^{105}$ Sadomasochism ${ }^{106}$ and drug use both involve risk of physical harm. ${ }^{107}$ Although the harm is only to the user, it is the state's place to protect its citizens' bodies even if it is not its place to protect their souls. Similarly, the state has an interest, quite removed from soul protection, in preserving the lives of its citizens. Thus, its anti-suicide laws do not implicate Establishment Clause concerns.

\footnotetext{
99. 413 U.S. 139 (1973).

100. Id. at 140.

101. Id. at 142-43.

102. Id. at $141-42$.

103. See Carey v. Population Servs. Int'l, 431 U.S. 678 (1977); Eisenstadt v. Baird, 405 U.S. 438 (1972).

104. Barnes v. Glen Theatre, 501 U.S. 560,575 (1991)

105. See supra text accompanying notes 80-81.

106. At least to the extent that it causes or risks serious injury. See People v. Samuels, 58 Cal. Rptr. 439 (1967).

107. Arguably some unlawful drugs (e.g., marijuana) do less harm than some lawful substances (e.g., alcohol). See Wayne Hall et al., Who Project on Health Implications of Cannabis USE: A Comparative ApPraisal of the Health and Psychological Consequences of Alcohol, CANNABIS, NiCOTINE AND OPIATE USE, Aug. 28, 1995 (contained in original version, but deleted from official version) (Geneva, Switzerland: World Health Organization, Mar. 1998), available at www.sky.org/data/who/library/study; Michael Winerip, Binge Nights: The Emergency on Campus, N.Y. TIMES, Jan. 4, 1998, at 4A ("[T] he problems of marijuana are different. They're not as severe. You don't have the violent behavior, you don't have the sexual aggression, you don't have the poisoning."). To the extent that this observation is accurate, it may suggest some lack of wisdom in punishing marijuana use. It does not suggest an Establishment Clause problem.
} 


\section{PRotecting Religion's VoICE IN THE PUblic SQUARE}

In this section, I wish to emphasize that no part of this thesis is intended to banish religion from the public square, ${ }^{108}$ or even subject religion to an inferior status in the debate on public issues. Although religion is not, and should not be, the state's golden child, neither should it be the state's whipping boy. Rather, most of the Supreme Court's better reasoned decisions have emphasized the importance of the state's "wholesome "neutrality.",109 As I have argued elsewhere, neutrality is a salutary principle. ${ }^{110}$

But one might argue that thus far I have suggested that legislation might be unconstitutional if supported primarily by religion but constitutional if it is supported by non-religious groups. How is that neutral? The answer is that my thesis extends only to legislation that compels others to act in a manner that has no secular value and thus forces all citizens to act in accordance with the religious dictates of some. Put differently, these are cases in which religion is being used as a sword to force heretics to toe the religious line under pain of criminal penalty.

Cases in which religion is used as a shield do not preclude religious argument at all. For example, suppose that a community zones a six-block area as a historic district, whose buildings cannot be expanded. Assume further that Carl is the minister of a church, located in the historic district, which wishes to expand. The Town Planning Board may, if it chooses, accommodate Carl's desire to expand his church. ${ }^{111}$ Carl is certainly free to argue to the planning board that: "You have no higher duty than the support of God. Please grant our variance."

Carl might find it wiser to rely on other grounds as well, such as the relative conformity of the planned expansion to generally applicable historic district guidelines. ${ }^{112} \mathrm{He}$ is not, however, required to do so. Furthermore, the town is not required to believe that the expansion is in conformity with the general parameters for the historic district in order to grant the variance. Should the town desire to grant the variance, solely on the ground that it wishes to support the church's free exercise of religion, it is totally free to do so. ${ }^{113}$

108. See Richard John Neuhaus, The Naked Public SQuare: Religion and Democracy in AMERICA (1984).

109. Abington Sch. Dist. v. Schempp, 374 U.S. 203, 222 (1963).

110. See Arnold H. Loewy, The Positive Reality and Normative Vinues of a Neutral Establishment Clause, 41 BRANDEIS L.J. 533 (2003); Arnold H. Loewy, Rethinking Government Neutrality Towards Religion Under the Establishment Clause: The Untapped Potential of Justice O'Connor's Insight, 64 N.C. L. REV. 1049 (1986).

111. Current Religion Clause jurisprudence permits, but does not compel, a religious accommodation under these circumstances. See, e.g.. City of Boerne v. Flores, 521 U.S. 507 (1997).

112. See, e.g., Kent Greenawalt, Religion and American Political Judgments, 36 WAKE FOREST L. REV. 401 (2001).

113. Justice Stevens is the only justice currently sitting on the Court who would disagree with this statement. See his concurrence in Boerne, where he considered just such an exemption and rejected the constitutionality of a statute that he concluded "provided the Church with a legal weapon that no atheist or agnostic can obtain." Boerne, 52 I U.S. at 537 (Stevens, J., concurring). 
Beyond the use of religion as a shield, religious Americans are entitled to use religiously-based arguments in debate. Suppose that Dianne's belief in capital punishment is primarily informed by the biblical admonition of an "eye for eye." 114 Suppose further that Dianne is a legislator. She is free to argue this position in the legislature in order to maximize the availability of capital punishment. ${ }^{115}$ Unlike the situation in regard to morals legislation, passage of this law requires nobody to adhere to a religious position.

Additionally, religious arguments do not get a free pass. In a church debate, Dianne's assertions can be met only by one who argues either that the Bible did not mean what it said or that it has been countermanded by some later biblical admonition. ${ }^{116}$ In the legislature, the debate is more openended. Biblical passages can be contradicted by quotes from Voltaire, Shakespeare, Mark Twain, or simply by the logic of Eric, another legislator, who doesn't believe that "eye for eye" ${ }^{\text {"117 }}$ is good public policy. ${ }^{18}$

Of course, the religious argument is open to both sides of the debate. Thus, Florence, another legislator, might argue that biblical phrases such as "[v]engeance is mine ... saith the Lord" "19 or "[j]udge not that ye be not judged" 120 counsel against capital punishment. And, as with Dianne, she too can be met with a religious pro-capital punishment response from Dianne, or a non-religious utilitarian pro-capital punishment argument from Glenn, another legislator. The point is that religion can be a part of the public debate, but it has no privileged position.

Indeed, so long as nobody is punished for failing to toe the religious line, I suggest that the community can enact legislation at the behest of a religious group. The facts of Clayton v. Place, ${ }^{121}$ an Eighth Circuit case, are instructive. In that case, the School Board, largely motivated by the conservative religiosity of its community, refused to allow dances to be held on school premises. ${ }^{122}$ The Eight Circuit upheld the School Board's policy,

114. Deuteronomy 19:21 " Show no pity: life for life, eye for eye, tooth for tooth, hand for hand, foot for foot."); Leviticus 24:20 ("[F]racture for fracture, eye for eye, tooth for tooth. As he has injured the other, so he is to be injured.").

115. Of course, to the extent that "eye for eye" calls for more frequent imposition of capital punishment than the Eighth Amendment allows, Dianne's view cannot be implemented. But this has nothing to do with its religiosity. It is treated exactly the same as one who would like to maximize capital punishment for utilitarian reasons.

116. See Matthew 5:39 ("turn ... the other [cheek]").

117. Deuteronomy 19:21; Leviticus 24:20.

118. For this reason, I disagree with those who have argued that it is improper for legislators to base their arguments on religion. See generally the articles collected in Symposium: The Role of Religion in Public Debate in a Liberal Society, 30 SAN DIEGo L. REV. 643 (1993). Specifically, see Robert Audi, The Place of Religious Argument in a Free and Democratic Society, 30 SAN DIEGo L. REV. 677 (1993); and Kent Greenawalt, Grounds for Political Judgment: The Status of Personal Experience and the Autonomy and Generality of Principles of Restraint, 30 SAN DIEGO L. REV. 647 (1993). On the other hand, it may be imprudent because in most legislatures, reliance on religion simpliciter is not likely to carry the day. See Greenawalt, supra note 112, at 416.

119. Romans 12:19 (King James).

120. Matthew 7:1 (King James).

121. 884 F.2d 376 (8th Cir. 1989), reh'g en banc denied, 889 F.2d 192 (8th Cir. 1989).

122. Clayton, 884 F.2d at 377. 
notwithstanding the School Board's religious motivation. ${ }^{123} \mathrm{I}$ believe that the case was correctly decided.

Let us first consider a school board's options. There are very nearly an infinite number of extracurricular activities that a school board can sponsor. A very small partial list might include football, ceramics, debating, chess, and school dances. Most school boards sponsor some, but not all, of these activities. Which one(s) it sponsors is up to the individualistic judgment of each board. There is no reason to assume as a starting point that any given school board will support a particular activity, such as dancing.

Assume that a school board sponsors football and ceramics, but does not sponsor debating, chess, or school dances. Heather approaches the school board, asking it to sponsor chess. The board refuses. Irene approaches the school board, asking it to sponsor a school dance. Again the board refuses. It seems clear that Heather could not expect judicial help in forcing the school board to overturn its decision. Rather, Heather's remedy would be to meet with her friends after school and play chess, independent of the school.

Obviously, Irene has a similar remedy. She and her friends can organize a dance, which is perfectly lawful in the community so long as she does not hold it on school grounds. ${ }^{124}$ Her situation is not significantly different from Heather's. Of course, if the community outlawed dancing completely, the case would be very different. Making Irene a criminal for dancing would be an extreme form of the morals simpliciter legislation that the Establishment Clause should forbid a state from enacting. ${ }^{125}$

A mere failure to facilitate dancing is another matter. A state has a constitutional duty not to interfere with most early and mid-term abortions, ${ }^{126}$ but it has no constitutional duty to finance them. ${ }^{127}$ Similarly, it has a constitutional duty not to interfere with private homosexual behavior, ${ }^{128}$ but nobody would suggest that it is required to provide places for homosexuals to meet one another. I suggest that providing a place to hold dances falls in the same category. The school board need not do it. ${ }^{129}$ This conclusion assures religious groups equal, but only equal, citizenship.

To illustrate further, assume that a different school board initially chooses to sponsor debating, chess, and school dances. Suppose that Joe advocates that the school board discontinue its sponsorship of debate because he believes that debate training will teach the students to be insincere.

123. Id. at $380-81$.

124. Id. at 379 .

125. I am assuming that the school board cannot make a credible secular argument that high school students are too young to consent to dance in the same way that a state could legitimately argue that they are too young to consent to sexual intercourse or drink beer.

126. See Planned Parenthood v. Casey, 505 U.S. 833, 846 (1992); Roe v. Wade, 410 U.S. 113, 16263 (1973).

127. See Harris v. McRae, 448 U.S. 297, 326-27 (1980).

128. Lawrence v. Texas, 123 S. Ct. 2472, 2483 (2003).

129. Cf. Dallas v. Stanglin, 490 U.S. 19, 28 (1989) (holding that ballroom dancing is not protected by the Freedom of Speech Clause of the First Amendment). 
The other side argues that debate is a positive experience for students that can only help develop their minds and their self-esteem. ${ }^{130}$ Assume that Joe's arguments prevail and the school board refuses to sanction debate. Joe's opponents could not go into court and compel continued school sponsorship of debate.

Now, assume that Kathleen, a devout Baptist who believes that dancing erodes the moral values of children, asks the school board to discontinue its sponsorship of dance. The other side argues that dancing is a fine, healthy activity that in no way harms children. Let us assume that Kathleen's arguments prevail, in part because much of the school board and the community have like-minded religious perspectives. If we say that Joe and his friends could successfully remove debate from the high school but that Kathleen and her friends could not successfully remove dance, we would be according religious adherents second-class citizenship.

It is not necessary to do this. So long as religion is disabled from making non-adherence to its moral code a crime, the values underlying the Establishment Clause are protected. It is not necessary to render religion a pariah in its own community.

\section{THE TEST AS APPLIED TO GRISWOLD AND ROE}

The scope and limitation of my proposed thesis can be helpfully sharpened by analyzing Griswold $v$. Connecticut, which created the right to privacy, ${ }^{131}$ and Roe $v$. Wade, which significantly embellished it. ${ }^{132}$ For the reasons that follow, I conclude that the Griswold statute could have been invalidated on Establishment Clause grounds but that the Roe statute could not have been.

\section{A. Griswold v. Connecticut}

The statute at issue in Griswold forbade the use of "any drug, medicinal article or instrument for the purpose of preventing conception."133 The case concerned the constitutionality of this prohibition as applied to married couples. ${ }^{134}$ The moral/religious basis of the law in a state with a substantial Catholic population ${ }^{135}$ practically cried out for recognition, yet that was not the basis of the arguments. The state primarily argued that if married people

130. See, e.g., 60 Minutes (CBS television broadcast, June 8, 2003) (discussing the Wallbrook Warriors, an inner-city debating team that has helped many members succeed in the classroom).

131. Griswold, 381 U.S. at 484.

132. Roe v. Wade, 410 U.S. 113, 162-63 (1973).

133. Griswold, 381 U.S. at 480 (quoting CONN. GEN. STAT. \$ 53-32 (1958 rev.)).

134. Id.

135. In fact, in 1965 Catholics made up nearly half of the total population of Connecticut. According to The Official Catholic Directory, of the 2,795,150 Connecticut residents in 1965, 1,239,529 were Catholic. See P.J. Kennedy, The Official Catholic Directory 118 (Diocese of Bridgeport), 358 (Archdiocese of Hartford), 619 (Diocese of Norwich) (1966). 
could use contraceptive devices, they would be more likely to have them. ${ }^{136}$ If they had them, they would be more likely to engage in extramarital affairs because there would be less concern about a pregnancy resulting therefrom. ${ }^{137}$ Thus, to deter extramarital affairs, the anti-use law was necessary, even in marriage. ${ }^{138}$ As Justice White understated:

This reasoning rests on the premise that married people will comply with the ban in regard to their marital relationship, notwithstanding total nonenforcement in this context and apparent nonenforcibility, but will not comply with criminal statutes prohibiting extramarital affairs and the anti-use statute in respect to illicit sexual relationships, a premise whose validity has not been demonstrated and whose intrinsic validity is not very evident. ${ }^{139}$

So why did the state eschew the morality argument for a utilitarian argument that could hardly be made with a straight face? I suggest that it may have been to avoid the argument that the legislation violated the Establishment Clause. Given the petitioner's laundry list of possible constitutional violations, ${ }^{140}$ it is difficult to believe that she would not have argued the Establishment Clause if Connecticut had seriously relied on the deontological impropriety of the marital use of contraceptive devices. I would go further and suggest that where the proffered justification is so incredible as to defy belief, and there is a plausible explanation that involves enacting the religious views of a substantial portion of the state's citizenry into law, the law should be analyzed under the Establishment Clause.

Let us assume that prior to Griswold, a law-abiding married agnostic couple, Larry and Mary, tried very hard to employ the state-approved (and by no coincidence at all, Catholic Church-approved) rhythm method of birth control. ${ }^{141}$ Assume further that their nervousness at the possibility of its not working led to a great strain in their relationship. Thus, out of desperation, and much to the dismay of their law-abiding character, they purchased and used a prophylactic. ${ }^{142}$ Finally, assume that a vindictive neighbor gave a false, but credible, tip that Larry and Mary were dealing drugs from their home. $^{143}$

136. Griswold, 381 U.S. at 498 (Goldberg, J., concurring).

137. Id.

138. Id.

139. Id. at 506-07 (White, J., concurring).

140. Id. at 484 (suggesting emanations and penumbras from the First, Third. Fourth, Fifth, and Ninth Amendments, as well as the Due Process Clause; however, not predicating the First Amendment on religion).

141. See State v. Nelson, 11 A.2d 856, 862-63 (Conn. 1940) (upholding the Connecticut anti-birth control law); Commonwealth v. Gardner, 15 N.E.2d 222, 224 (Mass. 1938) (upholding the Massachusetts anti-birth control law), appeal dismissed, 305 U.S. 559 (1938).

142. A not unheard of practice, even among law-abiding pre-Griswold Connecticut citizens.

143. Compare Lawrence v. Texas, 123 S. Ct. 2472, 2475 (2003), where a false report of a disturbance led to the police presence that discovered the defendants' then unlawful sex act. 
Upon searching their home pursuant to a valid warrant, the police found no drugs but did find a used prophylactic in the bedroom trashcan. ${ }^{144}$ After some police questioning, ${ }^{145}$ Larry confessed that he had used it while having sexual intercourse with his wife. He and Mary were promptly arrested for violating Connecticut's anti-use statute.

If at Larry and Mary's trial, the state were to contend that contraceptive use is per se immoral, how should the court resolve the case? I contend that the unlucky couple should be set free unless the state could establish a better reason for the statute than abstract morality. Assuming that the state eschews the ridiculous anti-adultery rationale that Justice White lampooned in his Griswold concurrence, is there anything that it could argue?

Plausibly the state could argue that sexual relations engaged in for the purpose of procreation are so inherently superior to non-procreative sex that the state wants to ensure everyone's maximum pleasure. There are philosophers who have made that argument, ${ }^{146}$ but, to put it mildly, it cannot seriously be claimed as a universal truth. Larry and Mary were driven to become lawbreakers in order to save their sanity and their marriage. And, while I may have slightly overdrawn these characters, there are surely many more citizens who do not find sex with the prospect (risk) of procreation more satisfying than sex with a contraceptive.

Thus, I cannot believe that any significant number of religious skeptics would support Connecticut's anti-contraceptive law. Consequently, under the proposed test, it violates the Establishment Clause.

\section{B. Roe v. Wade}

Roe would come out quite differently under the Establishment Clause. Undoubtedly there is substantial religious sentiment for the proposition that a fetus ${ }^{147}$ is a human being, complete with a soul, from the moment of conception. Obviously, the question of the precise moment of ensoulment (as-

144. Cf. Griswold, 381 U.S. at 485-86 (Douglas, J., concurring) ("Would we allow the police to search the sacred precincts of marital bedrooms for telltale signs of the use of contraceptives? The very idea is repulsive to the notions of privacy surrounding the marriage relationship.").

145. Of course, Miranda v. Arizona, 384 U.S. 436 (1966), had not been decided until a year after Griswold.

146. See John M. Finnis, Law, Morality, and "Sexual Orientation," 69 Notre DAME L. REV. 1049 , 1067 (1994).

[S]exual acts are not unitive in their significance ... unless they have not only the generosity of acts of friendship but also the procreative significance, not necessarily of being intended to generate or capable in the circumstances of generating but at least of being, as human conduct, acts of the reproductive kind-actualizations, so far as the spouses then and there can, of the reproductive function in which they are biologically and thus personally one.

Id. See also Michael J. Perry, Religion in Politics: Constitutional and Moral Perspectives 84-96 (1997) (critiquing the piece); John M. Finnis, The Good of Marriage and the Morality of Sexual Relations: Some Philosophical and Historical Perspectives, 42 AM. J. JURIS. 97 (1997).

147. I use the term to apply generically to the entity created at conception until its birth. Of course, I am aware that technically the conceptus/zygote/embryo/fetus does not achieve fetal status until some time after the moment of conception. Nevertheless, for the purpose of simplicity, I will use the term to describe the entity from the moment of conception until birth. 
suming that there is such a thing) is none of Caesar's concern. On the other hand, protection of human life is.

Fetal value is not a question entirely dependent on one's religious viewpoint. Obviously, one who believes in early ensoulment will want to protect the ensouled entity. On the other hand, some quite non-religious people support fetal protection from the moment of conception. ${ }^{148}$ This is not surprising inasmuch as a fetus, whatever else it may be, is an organism with a full set of human genes. ${ }^{149}$ So, because a substantial number of religious skeptics support fetal protection, and their view is predicated on purposive morality, the Establishment Clause is not an appropriate home for abortion rights. ${ }^{150}$

\section{CONCLUSION}

Morals legislation has been a major problem for the Supreme Court. In Griswold, a bare majority of the Court relied on penumbras and emanations from various Amendments to create a zone of privacy. ${ }^{151}$ In Roe, the right to privacy moved to the Due Process Clause of the Fourteenth Amendment. ${ }^{152}$ In Bowers, the Court concluded that morality was sufficient to trump Due Process or penumbral privacy. ${ }^{153}$ Finally, in Lawrence, the Court concluded that something more than morality was needed to justify such intrusive legislation. $^{154}$

Throughout these cases there have been justices unwilling to join because of the absence of a specific constitutional provision justifying the result. For example, in Griswold, Justice Stewart's most flattering description of the Connecticut statute was that it was "uncommonly silly." 155 Nevertheless, he refused to invalidate the law because uncommon silliness does

148. For example, The Atheist and Agnostic Pro-Life League Member List, available at http://www.godlessprolifers.org/members.html (last modified Sept. 23, 2003), demonstrates just such a group and contains well over one hundred registered members.

149. See 2 WARREN T. REICH, ENCYCLOPEDIA OF BIOETHICS 849 (1995) ("Few knowledgeable observers would doubt that when fertilization is completed, it has established the significant genetic foundation for the resulting person-to-be.")

150. See laurence H. Tribe, American Constitutional law 1350 (2d ed. 1988), for agreement with this proposition. But see Laurence H. Tribe, The Supreme Court, 1972 Term-Foreward: Toward a Model of Roles in Due Process of Life and Law, 87 HARV. L. REV. 1, $21-25$ (1973) (arguing to the contrary). Whether abortion rights should be protected under some other principle is beyond the scope of this Essay. I have argued elsewhere that Roe was wrong when it was decided and that it should have been overruled. See Arnold H. Loewy, Abontive Reasons and Obscene Standards: A Comment on the Abortion and Obscenity Cases, 52 N.C. L. REv. 223 (1973); see also Arnold H. Loewy, Why Roe v. Wade Should be Overruled, 67 N.C. L. REV. 939 (1989). Now that its overruling has been considered and specifically rejected, the landscape has changed in regard to continuity and stability. See Planned Parenthood v. Casey, 505 U.S. 833 (1992). For that reason, it is no longer clear to me that Roe should be overruled.

151. Griswold, 381 U.S. at 484.

152. Roe, 410 U.S. at 129.

153. Bowers, 487 U.S. at 186.

154. Lawrence, 123 S. Ct. at 2472.

155. Griswold, 381 U.S. at 527. 
not equate to unconstitutionality. ${ }^{156}$ Justice Thomas took an identical position in regard to the Texas sodomy law in Lawrence. ${ }^{157}$

My proposed test is largely a response to these justices. Like Justices Stewart and Thomas, I agree that ordinarily the Court should not invalidate laws because of their silliness. Justices do take an oath, after all, to support the Constitution. And it is certainly reasonable to refrain from invalidating laws that do not clearly violate some provision of that document.

Unlike the penumbras and emanations rationale of Griswold, or the amorphous Due Process privacy of Roe and Lawrence, my proposal is predicated on the core principle of a basic constitutional provision, the Establishment Clause. One need not make up constitutional rights to conclude that the Establishment Clause means, at least, that no citizen can be made a criminal for non-adherence to another's religious precepts.

The major issue is how to separate a legitimate state command from a state-enforced religious obligation. My answer is to first look to see whether the state commands adherence to a religious precept. If it does, I ask whether the state has a purpose beyond religious conformity. To measure that, I ask whether a substantial number of religious skeptics would support the proposal. If they would, the legislation is constitutional. If they would not, the legislation should be invalidated.

156. Id

157. Lawrence, $123 \mathrm{~S}$. Ct. at 2498 (Thomas, J., dissenting). Justice Thomas, in fact, explicitly quoted Griswold: "I write separately to note that the law before the Court today is . . uncommonly silly." Id. 